PETAR ČOVO, M.Sc.

Department of Economics

Mihovila Pavlinovića bb, HR-23000 Zadar,

Republic of Croatia

HRVOJE BARIČEVIĆ, Ph.D.

E-mail: hrvoje@pfri.hr

University of Rijeka

Faculty of Maritime Studies

Studentska 2, HR-51000 Rijeka, Republic of Croatia

ANTE VUKUŠIĆ, B.Eng.

E-mail:policija@mup.hr

Ministry of the Interior

Ulica grada Vukovara 33, HR-10000 Zagreb,

Republic of Croatia

\title{
RELIABILITY OF TECHNOLOGICAL PARAMETERS IN ROAD INFRASTRUCTURE MAINTENANCE
}

\begin{abstract}
It may be well said that the most used indicator of the quality of any technical system is reliability. Basically, this indicator shows the probability of proper technical system functioning within certain time period and under given operating conditions. To ensure that a system under construction possesses adequate given pre-defined characteristics and reliability indicators, it is necessary to plan the reliability and apply suitable methods when new technical systems are developed. Road represents an elementary traffic subsystem, as well as a technical subsystem, constructed by the society in order to meet the communication needs. Its purpose is to enable traffic system functioning. If a road is seen as a system, one can observe the features determining the structure and the principal on which its function is based. The road functioning itself is characterized by a variety of features, the most important being the management characteristic and specific social interest, categorization structure, and roadway condition. To enable smooth and safe traffic, roads should be of prescribed technical and usage levels. Reference is made specifically to road maintenance in the Primorje-Gorski Kotar County.
\end{abstract}

\section{KEYWORDS}

infrastructure, terotechnology, road network, maintenance, theory of benefit

\section{INTRODUCTION}

The development of the theory of reliability has been the result of an enormous technical and technological progress in the last century. In time, increas- ingly complex systems within automated processes have been increasingly replacing human activities, and in turn, the systems have to meet certain standards concerning proper functioning, utilization and maintenance. Consequently, it was necessary to deal with the issues of quantitative evaluation of system (or device) reliability, as well as to evaluate the effects of element reliability and system maintenance on its operation.

The change of the maintenance process status has coincided with the developments in the maintenance culture being the result of changes in business, and even more in gradual changes occurring in human attitude toward the environment. Not so long ago maintenance was actually a secondary activity. The crisis, which arose in the first "oil shock" in 1973, caused changes in business and living. Energy, raw material and capital price increases, as well as labor productivity decline (shorter working times, weakening of work motivation, of work discipline, etc.) all these had rendered maintenance one of the most important activities by its work complexity and intensity.

Technical system maintenance is not just an end in itself. Certain financial resources, shown as business costs, are invested to carry out specific activities. It is generally known that it is useful to invest, spend on the manufacturing process only if such expenditures yield some profit. Maintenance ${ }^{1}$ is a combination of all the technical, administrative and management procedures during the lifetime of an element, applied to keep or return an element into the status enabling it to perform a specific function. 


\section{DEVELOPMENT OF RELIABILITY}

The terms relating to the reliability of technical products and facilities are widely used in everyday life. Their meanings are usually implied. However, in order to quantitatively determine certain values and parameters characterizing those terms, it is necessary to define them precisely. An exact approach to this problem is based on the theory of reliability as a scientific discipline involving the study of models to be followed in planning, constructing, testing, production and utilization of technical systems, to enable their longer lifetime and consequently their optimum performance. Reliability as a term is described by a number of slightly different definitions. In the simplest terms, reliability is the ability of a facility (an element, a device, a system) to perform successfully its specified function under certain conditions, within a defined period of time. The actual meaning of reliability is best explained by the following definition:

- According to the American MIL Standard reliability implies a probability that a facility will perform its function in a defined time, under given conditions.

- The German DIN Standard defines reliability as an ability of a product or goods to satisfy, during their usage, conditioned requirements concerning their performances or maintenance of their features for a longer period.

- According to the Croatian Standard HRN EN 13306 , reliability is an ability of an element to perform its required function within a specific time interval. The term reliability is also used as a measure of the reliability performance and can be defined as a probability.

These definitions suggest the complexity of the reliability that, depending on the facility end-use and the conditions of its exploitation, can include failure-free performance, durability, accessibility for repair, or ability to maintain a set of certain properties within a longer period, where those properties may refer to the facility itself or some parts of it.

All the definitions include two crucial factors: operating time and conditions. The data on the facility reliability are relevant only for the specified time and under specified usage conditions.

Reliability as a probability (a number between 0 and 1 , or $0 \%$ and $100 \%$ ) can be expressed as a ratio between the number of successfully performed tasks and total number of tasks within the time specified for the system function:

$$
\hat{R}(t)=\frac{n_{1}(t)}{n(t)}
$$

where:

- $\hat{R}(t)$ is the evaluation of reliability,
- $n_{1}(t)$ is the number of successfully completed tasks within time $\mathrm{t}$,

- $n(t)$ is the total number of tasks completed within time $\mathrm{t}$,

- $t$ is the time specified for the system functioning.

Value $\hat{R}(t)$ represents the evaluation of reliability since the number of tasks $n(t)$ is finite. The actual reliability $R(t)$ is determined when the number of tasks tends towards infinity.

$$
R(t)=\lim _{n \rightarrow \infty} \hat{R}(t)
$$

Due to the discrepancy between the assessed and actual value the term assurance level is established. It is the probability that a parameter is within the given limits or above the bottom limit. Statistical evaluation is usually represented by intervals, with the probability i. e. assurance that the actual value will be within that interval. End points of the interval are called limits of assurance. For example, if a reliability of a system is 0.95 at the assurance level of 0.9 , it means that there is $10 \%$ risk that the reliability of that system is below 0.95 . Consequently, when constructing a certain system it is not enough to specify only the requirement for the reliability value that a system must meet, but the assurance level should be also added so as to be aware of the risk that might arise in the achievement of that reliability.

The mathematical assumption of reliability indicators is correlated with the theory of probability and mathematical statistics. When the reliability indicator is defined in practice, it is important that in the series of elements ${ }^{2}$ used to make conclusions on the element reliability, the causes of failure of each element are the same. Such series of elements is statistically homogenous. It is possible to realize a statistically homogenous series in practice. A homogenous series includes devices made in the same production line from the elements produced by the same producers.

The selection of indicators depends, essentially, on the system general end-use area, but it can be also affected by the importance of functions performed by that system. When the selection of the reliability indicators of a technical system is made, the following should be taken in account:

- the number of reliability indicators should be as small as possible,

- complex indicators obtained in the form of a group of criteria should be avoided,

- reliability indicators selected should enable checking at the designing stage,

- reliability indicators should be of a simple physical quality,

- reliability indicators should enable statistical (experimental) evaluation with special tests or by exploitation results, 
- reliability indicators selected should enable that the reliability is set in a quantitative form.

Prediction of the reliability of a system is a mathematical method based on experimentally obtained data on the reliability of an element. Depending on the aim set, as well as on the stage and development, the prediction of reliability can be made by the following three methods:

- method of equipment similarity,

- method of element listing,

- method of loading.

When the function of the failure density, failure intensity and reliability based on empirical data is determined, two approaches may be applied:

- the choice of one of statistical distributions most suitable for specific system (based on theoretical postulates and experience), or

- the definition of the so-called empirical functions of distribution density $f_{e}(f)$ based on the given data.

The distribution of data adopted in the first approach suggests that both appropriate failure intensity function and reliability function will be valid. This is the best method that should be used whenever possible. In any case, check can be done whether the data collected match the distribution adopted, and more appropriate distribution may be chosen, having in mind that the data have been collected for the preceding period, while the analysis and prediction are made for the future period, i. e. by the end of the system utilization. Further data collections may be used for additional corrections of the parameters of the distribution adopted, or for the corrections of the parameters selected.

\section{RELIABILITY PLANNING}

In recent years an increasing interest of manufacturers to demonstrate the quality of their products through reliability, availability, functional compatibility, and safety has been observed. Reliability is the most frequently used quality indicator for technical systems. It is an indicator of probability that a certain technical system will perform a required function within the specified time and under given operating conditions. To ensure that the system performs the function required with adequate, specified reliability characteristics and pre-defined indicators, the reliability should be planned and adequate methods applied when new technical systems are developed.

Reliability planning includes two independent groups of requirements:

- functional requirements,

- safety requirements.

These two distinct groups of requirements refer to various problems and needs. Functional requirements indicate that a system over time, at a certain degree of independence, will perform a function required and the one which it has been designed for. This involves two terms related to functionality: availability ${ }^{3}$ and reliability.

In case of the fixed assets (roads) maintenance vs. costs, advantages are longer lifetime, as well as reduced volume of losses that occur when the road exploitation is prevented due to failure. Thus the rate of investment in maintenance should be correlated with the benefit resulting from a longer and more secure usage time ${ }^{4}$ of technical systems.

As much as the maintenance system i. e. the capability of maintenance are important, as well as the capability of an element to continue in, or return into the status enabling it to perform the function required under the given usage conditions, when maintenance is carried out under given conditions by applying maintenance procedures and instruments providing technical system with the utmost reliability, so is the reduction of the maintenance costs. If one endeavours to get as many products (roads) as possible in a construction process, it may happen that the maintenance costs considerably decrease the profit.

If a system had to perform well then all its elements should operate correctly. There are examples when all the system elements are within tolerances, but if several are within the margin tolerances, then an effect arises resulting in failure or system failure. Such failures are characteristic for electronic systems. Contrary to this, there are situations when some system elements have failed ${ }^{5}$ but the system still performs well. This is usually the case for redundancy systems. Redundancy is defined as a configuration enabling a system to avoid downtimes even if some of its elements fail. Redundancy in an element means the existence of more than one instrument to perform the function required at a given moment. As reliability is the criterion of the system ability to perform satisfactorily when utilized, the introduction of a parameter that will measure the period is required. In continuous operation of a device it will be a time unit, while for the discontinuous operation in regular or irregular intervals the number of operations, cycles, revolutions, etc. may be used.

Any activity that should be done to realize some profit involves, as a rule, certain costs. Costs are, therefore, inevitable in any business. Thus, it is incorrect to attribute negative connotations to business costs as they are not negative by themselves.

\section{ROAD MANAGEMENT AS AN ACTIVITY OF SPECIAL INTEREST}

Road development is characterized by a number of management phases. The existing phase is based on 
the 1996 Law on Public Roads. The Law provides the classification of public roads into state, county and local ones. They are under the management of the Croatian Roads and county administrations.

Jobs that fall under simple reproduction are in charge of maintenance entities. As this activity exceeds the range of activities of the entities that manage the program realization, the Constitution has provided for a legal institute "an activity of special interest" enabling a sociopolitical community to regulate the mode of realization of such an interest, especially as the roads as a system lack sufficient organizational resources to resist impacts.

The characteristics of road infrastructure facilities are of technical, economical and institutional nature. Although roads are capital-intensive, at the same time they are low-accumulative, i. e. of low-earning capacity. Consequently, in addition to their own resources they have to engage the resources of other activities. The road infrastructure maintenance (particularly roads) is one of major issues of traffic and economic systems functions. This includes the assurance of its existing physical status to ensure smooth road traffic under any conditions. The maintenance of roads can be regular or emergency maintenance which will be discussed in more details later on.

Road network with road traffic is of crucial importance to the economy and integration of the territory of any country. Rapid growth of automotive industry and automobile mass production has required the modernization of existing and construction of new, modern roads. Croatian road network density amounts to $48.4 \mathrm{~km}$ roads per area of $100 \mathrm{~km}^{2}$, or $5.82 \mathrm{~km}$ per 1000 inhabitants. It is considerably less than in the developed regions of Central and Western Europe with $80 \mathrm{~km}$ roads per area of $100 \mathrm{~km}^{2}$.

Due to its outstanding geographical and traffic location the Primorje-Gorski Kotar County plays a major role in the economy widely exceeding its boundaries. Therefore, its internal and external communications in all directions and forms should be constantly provided. However, this is not always the case. Within its system of communications, roads and the road traffic have a special position.

And it is precisely this traffic segment in this area where the largest disruptions and congestions occur causing various direct or indirect losses. Major reasons for such a state are exceptionally adverse microclimatic conditions (in winter), particularly in Gorski Kotar, a large part of the County.

It should be pointed out that from among a wide range of problems (construction, modernization, maintenance, road net functioning) the least attention is still paid to the regular maintenance. Therefore, this write-up will help us to recognize the importance of the above problem. The maintenance itself can be divided into three segments:

- road maintenance in summer;

- road maintenance in winter;

- emergency road maintenance.

Regular maintenance is carried out on state, county and local roads. Only state road network of $506,250 \mathrm{~km}$ length, as the most loaded by average annual daily traffic and the crucial for the County economy, is treated further in this article.

\section{ECONOMIC INDICATORS IN ROAD INFRASTRUCTURE MANAGEMENT}

Road infrastructure includes all traffic arteries (roads and streets with substructures and superstructures), bridges, tunnels, viaducts, overpasses, underpasses, business establishments and places used to organize and perform traffic activity such as bus and truck stations, parking lots and garages located along the roads, equipment and traffic signs on traffic arteries and traffic facilities intended for signalling and control: traffic lights, horizontal and vertical signalling and other equipment for this application intended for pedestrians and drivers.

Road infrastructure construction and maintenance functioning is one of the fundamental characteristics of historical and economical rules at a certain stage of economic development. Theoretical concepts of road system financing, which fills any transportation and technological process from the material point of view, have undergone numerous evolution stages. Thus, today there are two different theoretical approaches to the solution of road financing issues.

One is the so-called causal theory based on the connection of the costs of roads borne by certain categories of vehicles to the so-called caused costs (American English terms "Cost Used", "Casual Responsibility").

Another approach is the so-called benefit theory that proceeds from expected benefits derived by certain vehicle categories from the utilization of roads (in English literature "Differential Benefits", "Anticipated Benefits"). This approach includes four basic theoretical approaches:

- the Benefit Theory,

- the Privilege Theory,

- the Ability Theory,

- the Equilibration Theory.

Other approaches to the solution of road financing issues exist in practice, wherein considerable attention is paid to the distribution of the infrastructure costs between direct and indirect users. 


\section{CONCLUSION}

In the late 1980s the number of road administrations endeavouring to change the programs of regular and emergency maintenance started to increase rapidly. Regular road maintenance programs as a whole are based on the cost-effective procedure concept, i. e. the lack of financial resources has been constantly present. The Primorje-Gorski Kotar County faces the same issues of the state roads regular and emergency maintenance as other counties in the Republic of Croatia since the financing system is centralized in the Croatian Roads. In this way even the planning at the stage of necessary investments, i. e. in order to bring the roads into a quite good state, is not possible.

However, the above analysis shows considerable progress, and indicates that the whole system has been brought closer to better road management as a whole, as well as to its segment of regular and emergency maintenance. Considering all the parameters elaborated in advance, we may conclude that it would be necessary:

- to develop permanently maintenance programs,

- to monitor maintenance requirements through state road monitoring,

- to define procedures in order to specify the most efficient procedures,

- to improve the system of the program efficiency feedback valuation,

- to seek and establish the system of authorized spending,

- to improve and promote partnerships with the companies, the concessionaires in state road net maintenance.

In this way the roads in Primorje-Gorski Kotar County will come closer to the European standards, the standards that other Croatian counties and the Republic of Croatia have been pursuing.

\author{
Mr. sc. PETAR ČOVO \\ E-mail:pcovo@unizd.hr \\ Sveučilište u Zadru, Odjel za ekonomiju \\ Mihovila Pavlinovića bb, 23000 Zadar, Republika Hrvatska \\ Dr. sc. HRVOJE BARIČEVIĆ \\ E-mail: hrvoje@pfri.hr \\ Sveučilište u Rijeci, Pomorski fakultet \\ Studentska 2, 51000 Rijeka, Republika Hrvatska \\ ANTE VUKUŠIĆ, dipl. ing. \\ E-mail: policija@mup.hr \\ Ministarstvo unutarnjih poslova \\ Ulica grada Vukovara 33, 10000 Zagreb, \\ Republika Hrvatska

\section{SAŽETAK}

\section{POUZDANOST TEHNOLOŠKIH PARAMETARA U FUNKCIJI ODRŽAVANJA CESTOVNE INFRASTRUKTURE}

Kod tehničkih sustava može se slobodno reći da je pouzdanost najčešće korišteni pokazatelj njegove kvalitete. To je u stvari pokazatelj koji govori kolika je vjerojatnost da će konkretan tehnički sustav funkcionirati ispravno u određenom vremenu i zadanim radnim uvjetima. Kako bi se osiguralo da sustav koji se razmatra ima odgovarajuće unaprijed definirane zadane karakteristike i pokazatelje pouzdanosti, potrebno je projektirati pouzdanost i primijeniti odgovarajuće metode prilikom razvoja novih tehničkih sustava. Cestovna prometnica predstavlja elementarni podsustav prometa kao i tehnički podsustav koji je izgradilo društvo da zadovolji potrebe učinkovite razmjene ljudi i dobara. Svrha njenog postojanja je da omogući djelovanje prometnog sustava. Promatra li se prometnicu kao sustav, zapaziti će se postojanje obilježja koja uvjetuju strukturu i načelo na kojemu se temelji njena služnost. Ukupno funkcioniranje cestovnih prometnica karakteriziraju brojna obilježja. Najvažnija su: obilježje gospodarenja i poseban društveni interes, struktura kategorizacije, $i$ stanje kolnika. $U$ radu se analizira održavanje, gospodarenje, te financiranje prometne infrastrukture. Za nesmetano i sigurno odvijanje prometa prometnice moraju biti na propisanoj tehničkoj i uporabnoj razini. Osvrt je upravo dan na održavanje prometnica u Primorsko-goranskoj županiji.

\section{KLJUČNE RIJEČI}

infrastruktura, terotehnologija, cestovna mreža, održavanje, teorija koristi

\section{REFERENCES}

1. Croatian Standard, HRN EN 13306:2001, second edition, December 2004

2. An element is any part, element, device, subsystem, functional unit, equipment or system that can be considered separately (HRN EN 13306:2001)

3. Availability is the ability of an element to perform the function required under given conditions within given time or within given time period, assuming that necessary external sources are provided (HRN EN 13306:2001) 
4. Usage time is, under given conditions, a time period commencing at a specified moment and ending when the failure frequency becomes unacceptable or when it is considered that an element, because of an error or any other important factor, cannot be repaired (HRN EN 13306:2001)

5. Failure is inability of an element to perform the function required. Upon failure, the element has an error either total or partial. "Failure" is an event, contrary to "error" which is a status. (HRN EN 13306:2001)

\section{LITERATURE}

[1] Banić, N., Čovo, P., Maintenance Efficiency as an Internal Variable, 12th International HDO Symposium, Maintenance 2006, Rovinj 2006

[2] Baričević, H.: Land Transport Technology, Faculty of Maritime Studies, 2001, Rijeka

[3] Baričević, H., Vukušić, A.: The Traffic Safety on RijekaZagreb Highway with Assistance by GIS Technology, Automatizacija u prometu, KoREMA, Zagreb/Copenhagen, 2005
[4] Belak, S., Belak, B., Čovo, P; Function Integration Method, 18th International DAAAM Symposium, Zadar, 2007

[5] Belak, S., Čovo, P.; Design for Maintenance, Euromaintenance "98 International HDO Symposium Proceedings, Maintenance 1998, Cavtat, 1998

[6] Čovo, P., Belak, S., Oršulić, M.; Maintenance Costs, 6th Scientific-Technical Conference on Maintenance, Split, 1999

[7] Čovo, P., Dobre, R.; Information, 12th International HDO Symposium, Maintenance 2006, Rovinj, 2006

[8] Čovo, P., Gržan, M., Belak, A.; Maintenance Capability Determination Based on CMR, 18th International DAAAM Symposium, Zadar, 2007

[9] Čovo, P.: Reliability of Technological and Economic Parameters in Land Transport Management, University of Rijeka, 2007

[10] Croatian Standard, HRN EN 13306, Second Edition, December 2004, ICS 01.040.03; 03.080.10

[11] Statistical Yearbook of the Primorje-Gorski Kotar County 